Nicola Polloni

\title{
Disentangling Roger Bacon's Criticism of Medieval Translations
}

\begin{abstract}
In his harsh polemics against the Latin curriculum studiorum, Roger Bacon often attacked Greek-and Arabic-to-Latin translations and their translators. Whereas many studies have focused on the pars destruens of Bacon's criticism, this contribution examines the pars construens implied by Bacon's discussion. By analysing the main arguments he levelled against some translators of his time, the paper shows how, behind a veil of criticism and rhetoric, Bacon envisioned a set of requirements that should be met by any translator. They constitute the profile of the 'good' translator, which is similar to another profile sketched by Bacon: that of the 'good' practitioner of philosophy and science, who needs to have a fluent knowledge of the ancient languages in order to properly understand the Latin translations as well. Accordingly, Bacon's criticism of medieval translations can be considered as an epiphenomenon of his wider syncretic approach to wisdom - its attainment being like resolving a puzzle whose pieces are scattered among different languages, cultures, and religions.
\end{abstract}

In his Compendium studii philosophiae, Roger Bacon declares that "were I to have power over the books of Aristotle I would have them all burned because it is nothing but a waste of time to study them, a cause of error, and a multiplication of error beyond what can be accounted for.' ${ }^{1}$ Bacon's pyromaniac attitude to Aristotle is not due to his dislike of the acclaimed philosopher, but rather to the Latin rendering of his works. Bacon points out that 'since the labors of Aristotle are the foundations of all of science, no one can estimate how great the damage is to Latins because of the bad translations philosophers have received." Apparently, nothing can be better than something, if the latter is a source of error and discord. Expanding on the same line of reasoning, Bacon observes that it would be better to do as Robert Grosseteste did (pace sua), when he 'entirely disregarded the books of Aristotle and their meth-

1 Roger Bacon, Compendium studii philosophiae, ed. T.S. Maloney (Oxford: The British Academy, 2018), p. 166: 'Si enim haberem potestatem super libros Aristotelis, ego facerem omnes cremari, quia non est nisi temporis amissio studere in illis et causa erroris et multiplicatio ignorantiae ultra id quod valeat explicari.' The English texts I quote from Bacon's Compendium have been translated by Maloney in his edition of Bacon's work.

2 Bacon, Compendium studii philosophiae, p. 166: 'Quoniam labores Aristotelis sunt fundamenta totius sapientiae, ideo nemo potest aestimare quantum dispendium accidit Latinis, quia malas translationes receperunt philosophi.'

Ә OpenAccess. (c) 2021 Nicola Polloni, published by De Gruyter. (cc) BY-NC-ND This work is licensed under the Creative Commons Attribution-NonCommercial-NoDerivatives 4.0 International License. 
ods' - at least according to Bacon. ${ }^{3}$ One might wonder, what was so bad about the Latin translations of Aristotle to motivate such harsh criticism by Bacon?

In the following pages, I want to discuss Roger Bacon's critique of the Latin translators and present a different interpretation of Bacon's stance. This topic has been studied by Gabriel Théry and Richard Lemay. ${ }^{4}$ In their discussion of Bacon's position, however, both scholars appear to have been quite unable to distinguish theory from rhetoric, purpose from persuasiveness, and the historical actor from the historical witness. As a consequence, the biases they see and blame in Bacon's criticism of the translators are mirrored by their own criticism of Bacon's words.

Roger Bacon directly criticizes the Latin translators in Opus maius, Opus tertium, and Compendium studii philosophiae. ${ }^{5}$ As often happens with Bacon's texts, these passages are interrelated, and Bacon's criticism is repeated with few modifications in the three works. This redundancy is connected to the functions that Bacon's critique was aimed to carry out within the theoretical structure of the three works. These functions are related to three levels of Bacon's line of reasoning that should be recalled. Firstly, Bacon's attack against the Latin translators is an expression of his epistemological reflections on the problem of the interpretative access to a written text. As we shall see, Bacon claims that Latin practitioners of science, philosophy, and theology need to have a basic knowledge of the ancient languages (Hebrew, Greek, and probably Arabic), in order to properly understand the translated texts they use. For this reason, translators and translations are criticized in the sections that Bacon dedicates to the study of languages in the three works.

Secondly, Bacon displays an analytic attitude in dissecting causes and effects that bad translators and lack of linguistic fluency have on Latinate knowledge. Such an attitude compels him to consider the work of the translators as both an error and a cause of error. As a consequence, he fragments the deceiving effects of their unreliable work into a plurality of despicable problems, from doctrinal controversies to medical malpractice. Thirdly, it should be recalled that both the study of languages and the treatment of the effects of bad translations are aspects of Bacon's discussion of his project of education reform. Both Opus maius and Opus tertium were aimed at persuading Pope Clement IV to sponsor this project. Therefore, Bacon's line of reasoning is intrinsically bound to the socio-cultural purposes that he

3 Bacon, Compendium studii philosophiae, p. 166: 'Neglexit omnino libros Aristotelis et vias eorum.' 4 See Gabriel Théry, 'Note sur l'aventure “bélénienne” de R. Bacon,' Archives d'histoire doctrinale et littéraire du Moyen Âge 13 (1950 - 51), pp. 129 - 47; and Richard Lemay, 'Roger Bacon's Attitude Toward the Latin Translations and Translators of the Twelfth and Thirteenth Centuries,' in Roger Bacon and the Sciences: Commemorative Essays, ed. Jeremiah Hackett (Leiden: Brill, 1997), pp. 25-47. In my examination, I will not discuss Rignani's article on the topic, because it reiterates Lemay's analysis and criticism almost to the letter. See O. Rignani, 'Ruggero Bacone su traduttori e traduzioni,' Doctor Virtualis 6 (2007), pp. 203-20.

5 See Roger Bacon, Opus maius, ed. J.H. Bridges (London: William and Norgate, 1900); Opus tertium, ed. N. Egel (Hamburg: Meiner, 2020), bk. I, pp. 180-94; and Compendium studii philosophiae, pp. $160-76$. 
wanted to achieve in leveraging the pope. ${ }^{6}$ The later Compendium studii philosophiae follows this tendency and reflects Bacon's disillusionment with the possibility of implementing his reform after the death of Pope Clement IV.

In my examination, I will focus mostly on the case of the philosophical translations discussed by Bacon. In fact, Bacon himself observes that the translations of philosophical works better exemplify problems and mistakes arising during the translating process than the translations of theological texts. ${ }^{7}$ I will proceed as follows. Firstly, I will examine Bacon's critique of the methods of translations and the possibility of translating from a language to another. Secondly, I will analyse the pars construens of Bacon's reasoning, so often left out of consideration by scholarship. Finally, in my conclusions I will address how Bacon's theory of translation is connected to contextual aspects related to the purpose and rhetorical coordinates of his texts.

\section{Critique of the Methods of Translation}

Roger Bacon appears to express some doubts about translatability as such. ${ }^{8} \mathrm{He}$ observes that every language is structured according to a series of grammatical, semantic, and stylistic peculiarities that cannot be rendered into the other language. As a consequence, 'it is not possible for what is done in one language through a unique variation to be conveyed properly and truthfully (proprie et veraciter) in another, especially in the case of the sciences, which present difficulties all their own.' ${ }^{\text {' For the }}$ same reasons, in the Opus maius he concludes that 'an excellent piece of work in one language cannot be transferred into another as regards the peculiar quality that it possessed in the former.' ${ }^{, 10}$

\footnotetext{
6 For a more general perspective on 13th-century Franciscans and the papacy, see Amanda Power, 'Franciscan Advice to the Papacy in the Middle Ages,' History Compass 5:5 (2007), pp. 1550-75. See also Jeremiah Hackett, 'Philosophy and Theology in Roger Bacon's Opus Maius,' in Philosophy and the God of Abraham: Essays in Memory of James Weisheipl OP, ed. Raymond James Long (Toronto: PIMS, 1991), pp. 55-71.

7 See Bacon, Compendium studii philosophiae, p. 172: 'Sed longe maior error accidit in philosophia translata, quia, si sancti erraverunt in suis translationibus, multo magis alii qui parum aut nihil de sanctitate curaverunt.'

8 For a historical account of how translation theory has discussed the problem of translatability, see Raquel De Pedro, 'The Translatability of Texts: A Historical Overview,' Meta 44:4 (1999), pp. 546-59. 9 Bacon, Compendium studii philosophiae, p. 160: 'Non est possibile ut quod in una lingua secundum proprietatem factum est explicetur proprie et veraciter in alia, et maxime de scientiis, quae sunt difficultates ex seipsis.'

10 Bacon, Opus maius, bk. III, pp. 66-67: 'Quod bene factum est in una lingua, non est possibile ut transferatur in aliam secundum ejus proprietatem quam habuerit in priori.' English trans. R. Belle Burke (Philadelphia: University of Pennsylvania Press, 1928), vol. I, p. 75.
} 
Bacon's doubts highlight a fundamental and controversial point which is still debated in translation theory. What does it mean to translate a text from one language into another? What is missed in this process, if anything? Bacon appears to reject the very principle of translatability: the translating process is unable to establish a true equivalence (proprie et veraciter) between the two languages. Bacon seems to imply that any translation always implies a semantic transfer: it is not a copy, but a new object epistemically characterized by a varying closeness to the original. Naïvely, a good translation could be one that gets as close as possible to the original text (the 'source domain') in its rendering into the other language (the 'target domain'). Accordingly, the translator may try to render into the target domain all the linguistic variables of the source domain at the levels of grammar, semantics, style, and even prosody. Yet, a translation cannot work as a mere mirror of the original text. The variables characterizing the source domain need to be rendered within the coordinates proper to the language of the target domain. Otherwise, the resulting text would be unintelligible, as Bacon observes referring to Jerome's stances on this issue. ${ }^{11}$

As is frequently the case with Bacon, however, one should not indulge too much in a single passage but rather look the bigger picture. Bacon is surely sceptical about the true equivalence between source and target domains. However, his scepticism does not entail a complete denial of the possibilities of making a reliable translation: it is primarily centred on stressing the difficulty of its completion. ${ }^{12} \mathrm{He}$ is not denying the possibility of making a reliable translation but stressing instead the difficulty of the task. As we shall see, there are good translators that make good translations, even if they are few. A good translator needs to be fluent in the languages of both source and target domains. Such fluency ideally enables them to move proficiently among the different sets of linguistic variables of the languages of both source and target domains, adapting the former to the latter. However, there are also many bad translators that make bad translations. The reason of their unreliability is simple: their method and skills - and therefore, their practice - are not good. Going beyond its abrasive rhetoric, one should appreciate the pars construens of Bacon's criticism: reliable translations are possible when some crucial conditions are met.

11 Concerning this point, Bacon refers to Jerome's remarks about the impossibility of making a reliable literal translation of Homer. See Bacon, Opus maius, bk. III, p. 67; Opus tertium, bk. I, p. 182; and Compendium studii philosophiae, p. 160. On Bacon's criticism of literal translations, see also Charles Burnett, 'Translating from Arabic into Latin in the Middle Ages: Theory, Practice, and Criticism,' in Éditer, traduire, interpreter: essais de methodologie philosophique, ed. Steve G. Lofts and Philipp W. Rosemann (Louvain-la-Neuve and Leuven: Peeters, 1997), pp. 71-72 in pp. 55-78.

12 From this point of view, I believe that Bacon was less committed to his pars destruens than it might appear. Indeed, it seems to me that he is not aiming at a simple rejection of translations as such, but rather trying to facilitate his own education reform through the criticism of the available translations. My interpretation of Bacon's doubts about the feasibility of literal translations follows this consideration. 
Gabriel Théry links Bacon's criticism to one particular method of translation: the bi-phasic word for word translations, which were commonly used by Arabic-to-Latin translators in Toledo. ${ }^{13}$ This method required the collaboration of two translators fluent in Arabic and Latin, respectively. Adopting a word for word approach, the former translated the Arabic term into Spanish vernacular and the latter rendered that term into Latin. Evidently, bi-phasic word for word translations imply different levels of translations beyond the apparent $(\mathrm{S} \rightarrow \mathrm{T})$ rendering of the text. ${ }^{14}$ As a consequence, the process of translation is a slippery slope where each translator must have linguistic fluency in two languages and textual reinterpretation can occur in three different stages:

1. The interpretation implied by the linguistic rendering of Arabic into Spanish, which is characterised by the first translator's expertise: $t_{1}(\mathrm{Ar} \rightarrow \mathrm{Sp})$.

2. The interpretation established at the inter-personal level of communication between the two translators: $t_{1} \rightarrow t_{2}$.

3. The interpretation entailed by the linguistic rendering of Spanish into Latin, which is in turn characterized by the second translator's expertise: $\mathrm{t}_{2}(\mathrm{Sp} \rightarrow \mathrm{Lat})$.

Clearly, two different aspects appear to carry a crucial function in defining the 'expertise' proper to each translator: (a) their fluency in Spanish and the source or target language, and (b) their mastery of the disciplinary contents of what they are translating. Albeit evident, this is a fundamental point. Knowledge of the relevant languages is a necessary yet not sufficient condition for a reliable translation. I can be fluent in English and able to translate a philosophical text from Italian into English. However, if I were trying to translate a specialized text from a discipline in which I have no expertise - for instance, an essay on practices of oil extraction in Saudi Arabia - I would probably make a rather poor translation. In order to make a good translation, I must have a preliminary knowledge of the epistemic and semantic coordinates of the text I am about to translate. And needless to say, I also need to know the target and source languages. As we are going to see, these two requirements are the criteria for a good translation to which Bacon refers throughout his critique.

In the Compendium, Bacon refers to bi-phasic translations indirectly, by naming some translators that used that method. His criticism focuses on both the variables mentioned above, but particularly on linguistic fluency:

13 See Marie-Thérèse D'Alverny, 'Les traductions à deux interprètes, d'arabe en langue vernaculaire et de langue vernaculaire en latin,' in Traduction et traducteurs au Moyen Âge: Actes du colloque international du CNRS organisie d Paris, Institut de recherche et d'histoire des textes, les 26-28 mai 1986, ed. Geneviève Contamine (Paris: Éditions du CNRS, 1989), pp. 193-206.

14 Albeit often neglected, the different epistemic levels implied by the bi-phasic model of translation show both richness and complexity of that process. 
Nor did he [Herman the German] know Arabic well, as he acknowledged, for he more assisted [in making] the translations than was a translator himself, since he retained Saracens with him in Hispania who took the lead in their translations. Likewise Michael the Scot ascribed many translations to himself, but it is clear that Andrew, a certain Jew, worked more on these. So Michael, like Herman, translated, but they knew neither the sciences nor languages. ${ }^{15}$

Bacon recalls that Herman the German and Michael Scot used the bi-phasic method to make their translations, collaborating with Arabic native speakers. The text underlines that both Michael and Herman lacked what they were supposed to possess: linguistic fluency and disciplinary mastery. In addition, Bacon criticizes both authors for having ascribed to themselves the translations, while they were working in teams. In his opinion, the Arabic native speakers 'worked more' than them on the translations, for which they took the credit. Given the text, one wonders whether Bacon is criticizing the bi-phasic method or just the attitude of the individuals - Herman and Michael - involved in it.

Théry's interpretation is grounded on three main claims that: (a) Bacon was not aware of how translations were actually made in Toledo; (b) he mistakenly ascribed most of the work to the Arabic native speaker rather than the Latin translator; and (c) he engaged hypocritically in his discussion of the translation teams working in Toledo and in England. I believe Théry's claims are ungrounded and based on a mistaken interpretation of both text and context.

Concerning the first point (a), there are no reasons to believe that Bacon was not aware of the details of the Toledan translating process. Bacon's text does not provide any clue pointing to his misunderstanding of the process or his lack of knowledge. To the contrary, it is very likely that Bacon had access to some accounts of how translations were made in Toledo. Although not all manuscripts circulating at the time included them, it should be recalled that many translations were accompanied by prefaces written by the translators. In some cases, these prefaces explicitly mention the translating process. The Latin translation of Avicenna's De anima - a work that Bacon surely knew, and which had been translated in Toledo by Abraham ibn Daud and Dominicus Gundissalinus - is a very good example of this tendency. The preface recalls that, '[h]ere you have the book translated from Arabic, as I have first uttered the [meaning of its Arabic] words in vernacular, one by one, while Dominicus, the archdeacon, has translated them into Latin, one by one.'16 Théry refers to Gundissalinus and Ibn Daud repeatedly claiming that Bacon did

15 Bacon, Compendium studii philosophiae, p. 174: 'Nec Arabicum bene scivit, ut confessus est, quia magis fuit adiutor translationum quam translator, quia Saracenos tenuit secum in Hispania, qui fuerunt in suis translationibus principales. Similiter Michael Scotus ascripsit sibi translationes multas sed certum est quod Andreas quidam Iudaeus plus laboravit in his. Unde Michael sicut Hermanus retulit, nec scivit scientias neque linguas.' Italics are mine.

16 Avicenna Latinus, Liber de anima seu Sextus de naturalibus, 2 vols, ed. S. van Riet (Louvain: Peeters; Leiden: Brill, 1968-72), vol. I, p. 4: 'Habetis ergo librum, nobis praecipiente et singula verba vulgariter proferente, et Dominico Archidiacono singula in latinum convertente, ex arabico translatum.' 
not know their works. ${ }^{17}$ In this case, too, Théry is overinterpreting the text. It is true that Bacon does not refer to either Gundissalinus or Ibn Daud in his critique of the translators. ${ }^{18}$ However, an absence of evidence is not evidence of an absence, and Bacon surely used many of the translations made by these translators either together or with other members of their team (e.g. Avicenna's De anima, Ibn Gabirol's Fons vitae, and so on). ${ }^{19}$ Therefore, Théry's claim that Bacon did not know how the Toledan translators worked is at best unsubstantiated.

Similarly, also Théry's second claim (b) that Bacon mistakenly ascribes much of the work to the first translator (the Arabic native speaker) appears to be unfounded. As I have mentioned above, the bi-phasic translating process implies three distinct levels of interpretative access directly bound to the target and source languages: Arabic to Spanish by translator $\mathrm{t}_{1}$, Spanish to Spanish from translator $\mathrm{t}_{1}$ to translator $\mathrm{t}_{2}$, and Spanish to Latin by translator $\mathrm{t}_{2}$. It is evident that both translators are responsible for this process and reinterpretations can happen at any of the three stages. It is also clear that the apparent process of translation ( $\mathrm{Ar} \rightarrow \mathrm{Lat}$ ) is a compound of two translations $(\mathrm{Ar} \rightarrow \mathrm{Sp}$ and $\mathrm{Sp} \rightarrow$ Lat). As a consequence, the rendering of the Latin text $(\mathrm{Sp} \rightarrow$ Lat) is mostly due to the Latin translator while the semantic unveiling of the original - corresponding to the initial interpretation of the text implied by $(\mathrm{Ar} \rightarrow \mathrm{Sp})$ - is mostly due to the Arabic translator.

As I have recently pointed out in relation to the Fons vitae, the difference in the translators' access to the text is crucial and may result in the translation's reinterpretation of the original texts. ${ }^{20}$ Bacon seems to bear in mind this question of epistemic access when he claims that most of the work was made by the Arabic-to-Spanish translator. Among the reasons why Bacon claims that a knowledge of languages is fundamental for the Latins much relevance is given to the access to the true meaning of the text. The same point seems to be implied by Bacon's reasoning on bi-phasic translations. The epistemic unveiling is indeed made by the Arabic-to-Spanish translator while the Spanish-to-Latin translator elaborates the words already interpreted

17 See Théry, 'Note sur l'aventure “bélénienne”,' p. 135: ‘A aucun moment de ses œuvres il n’a pris conscience du mécanisme des traductions tolédanes. C’est précisément pour remédier à leur ignorance linguistique que les traducteurs tolédans eurent recours à des juifs qui, eux connaissaient l'arabe. Si Roger Bacon eût connu ce stratagème, il n’aurait pas accusé Michel Scot ni les autres traducteurs, de larcin littéraire. Il ne les aurait pas accusé non plus d'ignorance de l'arabe.'

18 There are evident reasons why Bacon does not refer to Gundissalinus and Ibn Daud: his criticism is indeed focused on the Latin translations of Aristotle's works.

19 Bacon also knew Gundissalinus' own philosophical works, which he mentions twice in his Questions on Aristotle's Physics. See Roger Bacon, Questiones supra libros octo Physicorum Aristotelis, ed. F.M. Delorme and R. Steele (Oxford: Clarendon, 1935), pp. 44 and 59. See also Nicola Polloni, The Twelfth-Century Renewal of Latin Metaphysics: Gundissalinus's Ontology of Matter and Form (Toronto: PIMS, 2020), pp. 268-69.

20 See Nicola Polloni, 'Misinterpreting Ibn Gabirol? Questions, Doubts, and Remarks on the Latin Translation of the Fons vitae,' in Unravelling Ibn Gabirol's Metaphysics: Philosophical and Historical Studies, ed. Nicola Polloni, Marienza Benedetto, and Federico Dal Bo (forthcoming). 
by their team-member and renders them into Latin. Again, one should refrain from exaggerating this aspect: translations were the result of a team work, and both translators were accountable for the result. Nonetheless, Bacon seems to acknowledge the crucial significance of the Arabic translator in the process, something that Thery himself maintains elsewhere in his study. ${ }^{21}$

Théry's third claim (c) refers to Bacon's different treatment of the two Toledan translators he criticizes (Herman the German and Michael Scot) and Robert Grosseteste. I will not discuss Théry’s suppositions about Bacon's crypto-nationalism and his supposed 'sentiment de supériorité anglaise.' Luckily, yet painfully, history has buried such chauvinist biases. ${ }^{22}$ Théry's criticism is based on a short passage in which Bacon recalls that Grosseteste, not knowing Greek well, was helped by many adiuvatores. ${ }^{23}$ Notwithstanding this collaborative framework - which evidently collides with the 'fluency in languages' requirement - Bacon maintains that Grosseteste's translations are good. According to him, the reason of their reliability is that Grosseteste 'knew the sciences' - i.e. he had disciplinary mastery of the topics of the texts he was translating. In Théry's opinion, Bacon did not understand the 'différences de méthode' between the bi-phasic method in Toledo and the team-work translations by Grosseteste. ${ }^{24}$ Yet again, Théry's criticism seems to be ungrounded, both historically and theoretically. He does not mention either passage in which Bacon supposedly misconceives these translations or the way in which the translating methods should have been different. Cecilia Panti is currently editing a special issue dedicated to Grosseteste's translations, and that will significantly contribute to clarify this aspect. For the moment, I limit myself to stressing that, at least to my knowledge, there are not sufficient grounds to claim either of the two aforementioned points implied by Théry.

21 See Théry, 'Note sur l'aventure "bélénienne”,' p. 136: 'Dans ces versions tolédanes, le juif et le chrétien ont leur part de responsabilité respective et totale. C'est le juif qui traduit tout l'ouvrage arabe en romance et c'est le chrétien qui traduit tout l'ouvrage en latin, le juif et le chrétien se rencontrant dans une langue commune: le romance. C'est donc une profonde erreur d'attribuer, comme le fait Bacon, la part principale aux 'Sarrasins' et de rabaisser Hermann au rang d'auxiliaire.'

22 See Théry, 'Note sur l'aventure "bélénienne”,' p. 139: 'Roger Bacon est un anglais et il n’aime guère que les habitants de son île. C'est le sentiment de sa supériorité anglaise qui explique sans doute le parti pris de Roger Bacon vis-à-vis des Latins, en infériorité au point de vue pratique et commercial; en infériorité dans les sciences; en infériorité en philosophie et tout cela, à cause de leur ignorance des langues, qui les rend inaptes à tout.'

23 Bacon, Compendium studii philosophiae, p. 174: 'Quia Graecum et Hebraeum non scivit sufficienter ut per se transferret, habuitc multos adiutores.'

24 See Théry, 'Note sur l'aventure "bélénienne”,' p. 139: 'Roger Bacon ne s'est pas rendu compte que ces adjutores n'avaient absolument rien de commun avec les adjutores des traducteurs tolédans. Il y a des différences essentielles entre les traductions par dichotomie élaborées à Tolède et les traductions par équipe, comme celles que nous attribuons à Robert Grossetête, considéré comme chef d'entreprise. Roger Bacon n’a rien discerné des différences de méthode dans les traductions médiévales. Peu lui importerait d'ailleurs, cette connaissance des méthodes.' 
Roger Bacon's stance seems to be rather different from Théry's interpretation of it. Bacon does not appear to be criticizing mainly the bi-phasic method of translation, either in Toledo or elsewhere. Of course, a good translator should be fluent in the languages of both source and target domains. Yet, the main problem seems to lay elsewhere, in the attitude of the translators that Bacon criticizes. Herman the German and Michael Scot do not meet the necessary criteria for making good translations: they have neither linguistic fluency nor disciplinary mastery. Furthermore, Bacon blames them for one additional reason: they have taken the credit for translations that resulted from a collaboration with other people who did more than them to make the translation. Indeed, they had access to the original text and interpretatively 'broke' it into the shared semantic coordinates that were then used and applied by the second translator. Accordingly, both Herman the German and Michael Scot fall into the category of those who are ignorant and, unaware of their ignorance: 'although they are in the densest shadows of error, they think that they are in the full light of truth. ${ }^{25}$ Both Herman the German and Michael Scot are exemplary cases of this reproachable attitude, while Grosseteste is not.

\section{Ingredients of a Good Translation ... and a Bad One}

It is now clear that for Bacon translations are possible, although it is rather difficult to make a good translation. This is why Bacon believes that one should know the ancient languages, namely, to properly study and understand a (translated) text. This point, too, is rather controversial. Mentioning a passage from the Compendium in which Bacon claims that Aristotle's works must be read in their original language, Richard Lemay points out Bacon's hypocritical attitude. In fact, while claiming that sources must be read in Greek or Hebrew, Bacon was working with translations (as his contemporaries did), without reading the original versions of those works. ${ }^{26}$ In his study, however, Lemay only quotes the first part of Bacon's text, which presents a fundamental qualification of the statement referred to by Lemay: 'Whoever wants to boast of a knowledge of Aristotle has to acquire it in the latter's own native tongue, for the inaccuracy of the translations is pervasive, both in theology and philosophy. ${ }^{27}$

The second part of the sentence clarifies the meaning of Bacon's words: direct access to the original version of the work has a corrective function in the considera-

25 Bacon, Opus maius, bk. I, p. 3: '(...) Cum sint in tenebris errorum densissimis, aestimant se esse in plena luce veritatis.' English tr. Belle Burke, vol. I, p. 4.

26 See Lemay, 'Roger Bacon's Attitude,' at pp. 43-44.

27 Bacon, Compendium studii philosophiae, p. 166: 'Quicumque vult gloriari de scientia Aristotelis oportet quod eam addiscat in lingua propria et nativa, cum ubique est falsitas translationum tam in theologia quam in philosophia.' Italics are mine. Lemay only refers to the first part of the sentence, stopping his quotation at 'propria et nativa'. 
tion of the bad translations that were circulating at the time. ${ }^{28}$ In other words, Bacon is observing that the translations of Aristotle were so poor that the only way to properly understand Aristotle was by reading the original text. He is not claiming that texts should be studied in their original languages, but that the knowledge of languages carries out specific corrective functions in relation to the translated texts. Elsewhere in the Compendium, Bacon makes this point quite clear by claiming that "not only is it fitting for Latins to know languages when using a translated text, it is impossible for them to understand its truth unless they have been instructed in other languages. ${ }^{29}$

These corrective functions are only partially related to the translating process. They cover different levels and ways in which one can approach a text, either translated to or written in Latin. Their effectiveness and utility are described in the sections on the study of languages in Opus maius, Opus tertium, and Compendium studii philosophiae. In the latter, Bacon gives his most detailed account of why Latinate practitioners need to attain at least a basic knowledge of Greek and Hebrew. These reasons can be summarized into three main groups concerning knowledge and its foundation, access, and practice. ${ }^{30}$

Foundation: (a) Latin grammar follows the Greek; (b) Latin knowledge is based on Greek and Hebrew knowledge; (c) imitation of the ancients, who knew Greek and Hebrew.

Access: (a) interpretation of ancient books; (b) appreciation of ancient authors' retractions; (c) understanding of Latin translations; (d) correction and understanding of calques; (e) access to all the works of Aristotle; (f) direct access to book prescinding from unreliable translations; ( $\mathrm{g}$ ) access to the untranslated books in philosophy, science, and theology.

Practice: (a) understanding and implementation of correct pronunciation, spelling, and etymology; (b) practice of wisdom.

In all these cases, knowledge of languages provides a set of corrective functions at the three levels of foundation, access, and practice, correcting possible misinterpretations, mis-renderings, mispronunciations, and so on. Accordingly, one should

28 My interpretation of Bacon's stance on the required linguistic knowledge of the source domain language to properly understand a translated text is stronger than Pérez González's. In his discussion of Bacon's theory, Pérez González maintains that translations are, for Bacon, the 'lesser evil'. See Maurilio Pérez González, 'Rogerius Bacon, teórico de la traducción,' in Scripta philologica de Media Latinitate Hispanica: Estudios sobre el latín medieval hispánico reunidos con ocasión de su $70^{\circ}$ cumpleaños, ed. Estrella Pérez Rodríguez and José Ramón Morala Rodríguez (León: Universidad de León, 2016), pp. 745-53. My interpretation is rather different: Bacon acknowledged that translations were necessary for the advancement of Latin knowledge but, in order for their content to be properly understood, readers must have a basic linguistic training.

29 Bacon, Compendium studii philosophiae, p. 160: 'Non solum est consonum ut Latini sciant linguas propter textum translatum, sed impossibile est quod veritatem <eius> intelligant nisi linguis instructi fuerint alienis.'

30 See Bacon, Compendium studii philosophiae, pp. 82-226. 
distinguish between two kinds of linguistic knowledge that, according to Bacon, are required by two different kinds of practitioners:

1. Philosophers, scientists, theologians: they must have a qualifying knowledge of languages enabling them to assess possible mistakes at different levels of their approach to the text.

2. Translators: they must have a linguistic fluency enabling them to render the linguistic and theoretical contents of the source domain into the linguistic and semantic coordinates of the target domain.

There is a fundamental difference in the linguistic expertise required by translators and non-translators. Concerning the former, I have already mentioned two of the ingredients necessary to make a good, reliable translation: linguistic fluency and disciplinary mastery. Bacon adds a third one: the trustworthiness of the translatable text. Both linguistic fluency and disciplinary mastery are mentioned by Bacon in clear terms:

For in order for a translation to be accurate the translator must know the language from which he translates and the language into which he is translating as well as the science which he seeks to communicate. 'But who is this and we shall praise him, for he has done wonders in his life.' Certainly none of those just mentioned knew anything worthwhile about languages and sciences; this is clear not only from their translations but also from the status of the persons. ${ }^{31}$

The first criterion that a translator should meet involves fluency in the languages of both the target (Greek/Hebrew/Arabic) and the source (Latin) domains. As we have seen, the criterion can be amended: Grosseteste was helped by other translators who knew Greek well and their translations are reliable. In turn, Michael Scot, too, was helped by another translator who had access to the Arabic original, but their translations are not reliable. This fact makes clear that linguistic fluency is a necessary yet not sufficient condition to make a good translation. The translator must know the discipline whose main coordinates characterize epistemically the text to be translated.

Quite surprisingly, Bacon appears to ascribe greater importance to this second condition than to the first. Although he is repetitive in stressing the importance of knowing the languages in order to translate, the case of Grosseteste is crucial in clarifying Bacon's overall theory. In the Compendium studii philosophiae, Bacon observes that,

31 Bacon, Compendium studii philosophiae, p. 172: 'Nam ad hoc quod translatio fiat vera oportet quod translator sciat linguam a qua transfert et linguam in quam transfert et scientiam quam vult transferre. Sed "Quis est hic et laudabimus eum? Fecit enim mirabilia in vita sua." Certe nullus praedictorum scivit aliquid dignum de linguis et scientiis, ut manifestum est illud non solum ex eorum translationibus sed ex conditionibus personarum.' Italics are mine. 
all the things he [William of Moerbeke] translates are false, and he corrupts the wisdom of the Latins, for only Boethius sufficiently knew the languages of all interpretations. Lord Robert alone, because of the length of his life and the marvellous methods he employed, knew the sciences more than any other men. Because he did not know Greek and Hebrew sufficiently to translate by himself, he had many helpers. ${ }^{32}$

Similar considerations are expressed in the Opus maius, where Bacon claims that, although the translator ought to be perfectly acquainted with the subject which he wishes to translate and the two languages from which and into which he is translating, Boethius alone, the first translator, had full mastery of the languages; and Master Robert, called Grosseteste, lately Bishop of Lincoln, alone knew the sciences. ${ }^{33}$

Boethius and Grosseteste are exemplary cases of the two criteria required to make a reliable translation: knowledge of languages and science, respectively. However, while the required linguistic fluency can be attained through team collaborations (as in the case of Grosseteste's adiuvatores), a lack of disciplinary mastery appears to be more problematic and difficult to attain. Bacon gives an example of this crucial limitation referring to Herman the German, who supposedly told him that he would not translate into Latin an Arabic text on logic because he did not have expertise on the subject. ${ }^{34}$ Leaving aside the question whether this conversation actually took place, the point that Bacon wants to make is that, in order to translate a text, you must be able to understand its meaning. But to understand its meaning, you need to have mastery of both its language and contents.

Although these two criteria do not seem to be problematic - present-day translators still follow them - Théry and Lemay harshly criticize Bacon's stance. This is another outcome of Bacon's antagonizing attitude and abrasive rhetoric that he used against many of his contemporaries. ${ }^{35}$ How could Bacon claim that translators like Gerard of Cremona or Michael Scot did not master the discipline of the works they were translating? Gerard of Cremona moved to Toledo in order to translate

32 Bacon, Compendium studii philosophiae, p. 174: 'Et ideo omnia transfert falsa et corrumpit sapientiam Latinorum. Solus enim Boethius scivit de omnibus interpretationibus linguas sufficienter. Solus dominus Robertus, propter longitudinem vitae et vias mirabiles quibus usus est, prae aliis hominibus scivit scientias. Quia Graecum et Hebraeum non scivit sufficienter ut per se transferret, habuitc multos adiutores.' Italics are mine.

33 Bacon, Opus maius, bk. III, p. 67: 'Oportet quod interpres optime sciat scientiam quam vult transferre, et duas linguas a quibus et in quas transferat. Solus Boethius primus interpres novit plenarie potestatem linguarum. Et solus dominus Robertus, dictus Grossum Caput, novit scientias.' English trans. Belle Burke, vol. I, p. 76. Italics are mine.

34 See Bacon, Compendium studii philosophiae, pp. 172-74.

35 See Lemay, 'Roger Bacon's Attitude,' p. 39: 'Without any serious examination of the translations, Bacon declares ex cathedra that these translators ignored both the sciences they were handling in the translations and the languages from which they were translating. Such a serious charge should have been thoroughly documented to escape being considered absolutely unconscionable.' 
the Almagest and was probably a master in the cathedral school of Toledo. ${ }^{36}$ Michael Scot wrote treatises in alchemy and astrology and became the official astrologer of the court of Fredrick II. ${ }^{37}$ It seems to me that Bacon cannot be referring to their mastery of those disciplines or their translations of those disciplinary texts.

Although Bacon's position is rather plain, a quick look at the translators he mentions can be useful in this respect. They are seven. Five are examples of bad translations: Gerard of Cremona, Michael Scot, Alfred the Englishman, Herman the German, and William of Moerbeke. In turn, two are exemplary of good translations: Boethius and Robert Grosseteste. As Théry observes, Bacon does not mention other translators, like Gundissalinus, and many others whose names he could probably have found in the prefaces of the translations he was using. The reason why Bacon mentioned these seven translators and no others is quite simple. They lived in different periods and areas and translated different sets of works and authors in either Arabic or Greek. Yet, they have one aspect in common: they all translated works authored by or ascribed to Aristotle. ${ }^{38}$ Indeed, Bacon limits his criticism to the Latin translations of Aristotle. Probably, he does so in virtue of the eminent and unique role that Aristotle's works played in the Latin system of knowledge. By attacking these translations, Bacon was certifying to the pope that Latin knowledge is rooted in mis-rendered texts and misinterpreted stances. Failure to appreciate how rhetoric and socio-political goal-directedness accompany and characterize Bacon's criticism of the translations would result in a simplistic misconception.

By targeting the Latin translations of Aristotle, Bacon seems to suggest that this set of work has an implicit status differentiating it from other sets of translations and texts. In other words, it seems that the criterion of disciplinary mastery should be applied to the specific case of Aristotle's works as if they were a sort of sub-genre. Such a strong interpretation would resolve the main frictions in Bacon's line of reasoning. It would place the examples of Herman the German recalled by Bacon on a different light: as Herman was unable to translate a work in logic because he did not know logic, so also the five bad translators were unable to translate Aristotle's works because they did not know Aristotle. It would clarify why Bacon attacks only some of the translators using the same method and working in the same place. Moreover, it would provide a different, fairer context to Bacon's criticism of translators who did

36 Concerning Gerard of Cremona's activities in Toledo, see Charles Burnett, 'Communities of Learning in the Twelfth-Century Toledo,' in Communities of Learning: Networks and the Shaping of Intellectual Identity in Europe, 1110-1500, ed. Constant J. Mews and John N. Crossley (Turnhout: Brepols, 2011), pp. 9-18; and Charles Burnett, 'The Coherence of the Arabic-Latin Translation Programme in Toledo in the Twelfth Century,' Science in Context 14 (2001), pp. 249-88.

37 On Michael Scot's biography, see Charles Burnett, 'Michael Scot and the Transmission of Scientific Culture from Toledo to Bologna via the Court of Frederick II Hohenstaufen,' Micrologus 2 (1994), pp. 101-26; and Charles H. Haskins, Michael Scot and Fredrick (Brussels: Weissenbruch, 1921).

38 For an overall perspective on the Latin translations of Aristotle, see Ezio Franceschini, 'Ricerche e studi su Aristotele nel Medioevo Latino,' in Aristotele nella critica e negli studi contemporanei (Milan: Vita e Pensiero, 1956), pp. 144-66. 
have the relevant expertise on some subjects, like Michael Scot, by limiting the critique to the case of Aristotle's works considered as a sort of sub-genre. In other words, the seven translators mentioned by Bacon would not be good or bad translators qua translators, but qua translators of Aristotle's works.

Nonetheless, a strong interpretation of the criterion of disciplinary mastery seems to clash with Bacon's own words about Grosseteste. As we have seen, Bacon claims that Grosseteste 'knew the sciences' but also that he 'entirely disregarded the books of Aristotle and their methods.' Yet, did Bacon actually believe that Grosseteste had no mastery of Aristotle's thought, as the latter passage maintains? This does not appear to be the case, considering that Bacon knew and bestowed great value on Grosseteste's interpretation of Aristotle, while it is undeniable that Grosseteste knew Aristotle very well. In Bacon's view, Grosseteste was antithetical to the Paris masters, their method, and their attitude toward Aristotle. The claim that Grosseteste disregarded Aristotle should be considered as expressing that distance from the Paris method which, according to Bacon, multiplied errors in the interpretation of Aristotle also because it is grounded on bad translations. ${ }^{39}$

In returning to the problem of the second criterion for good translations, Bacon does not clarify explicitly whether he considers the translations of Aristotle as a special case requiring a more specialized mastery (strong interpretation). Although this seems to be the case, the question is still open and less stringent interpretations are possible. In any case, Bacon's discussion is limited to the translations of Aristotle only. This fact restricts the scope of his criticism of the translators only qua translators of Aristotle's works, not qua translators in general. Bacon is not referring to Gerard's translation of Ptolemy or Scot's translation of al-Bitruji and is not assessing their expertise in those subjects. As a consequence, Bacon's critique cannot be generalized to consider those cases as well. ${ }^{40}$

Until now, I have discussed two main criteria formulated by Bacon and according to which it is possible to produce a good translation:

39 See Jeremiah Hackett, 'From Sapientes antiqui at Lincoln to the New Sapientes moderni at Paris, ca. 1260 - 1280. Roger Bacon's Two Circles of Scholars,' in Robert Grosseteste and the Pursuit of Religious and Scientific Learning in the Middle Ages, ed. Jack P. Cunningham and Mark Hocknull (Berlin: Springer, 2016), pp. 119-42.

40 Moreover, we should always bear in mind that any text - medieval or contemporary, disciplinarily specialized or not - is structured as an organized complex of epistemically intertwined claims and stances, style and rhetoric. Authors can and do give detailed accounts of events but also make rhetorical exaggerations. And authors never write with the aim to provide future historians with a reliable account of what they were doing, but with theoretical and practical goals bound to their personal context. This is why philosophy and history are different: we can evaluate a philosophical theory without contrasting it to the historical context, but we cannot reconstruct history without contextualizing what the author is saying. Accordingly, we should not mistake Bacon's theory of translation for an objective account of medieval translations. His criticism is aimed at something else and shaped by its functions to persuade the reader (the pope and any other reader) of the need to implement a profound reform of the education system in medieval Europe. 
1. Linguistic fluency of the languages of both domains $\mathrm{S}$ and $\mathrm{T}$, which should be individual but can be attained also by teamwork collaborations.

2. Disciplinary mastery, which needs to be individual and grounded on a number $n$ of features characterising the translatable text $Y$ as a member of a discipline $\Delta$.

These two criteria prescribe for the translator a set of requirements that they have to meet in order to deliver a good translation. Such are practical criteria that the translator must apply while working on the translation. However, there is a third criterion that is not related to the translator but to the translatable text. This is the criterion of the textual trustworthiness of the translatable text. In order to be reliable, a translation only needs the two criteria prescribed for the translators. When both are applied, the translating process $(\mathrm{S} \rightarrow \mathrm{T})$ produces a version $\mathrm{T}$ which represents the meaning of $\mathrm{S}$ at its different linguistic and semantic levels within the coordinates of the language of T. Evidently, a mutilated or corrupted version of the source domain $\left(\mathrm{S}_{\text {cor }}\right)$ will necessarily produce a mutilated or corrupted translation $\left(\mathrm{T}_{\text {cor }}\right)$ even when both criteria are met. In fact, it is highly unlikely for $\left(\mathrm{S}_{\text {cor }} \rightarrow \mathrm{T} \neg_{\text {cor }}\right)$ to happen. Accordingly, the criterion certifies the truthfulness of the text to be translated. This aspect is linked to the historical context in which the practitioner works and its social and political characteristics. On this point, Bacon observes that,

Since in these times the enemies of Christians such as the Greeks, Arabs, and Hebrews have the sciences in their own languages, they do not make available to Christians truthful books but mutilate and corrupt them all, and especially when they see men untutored in languages and the sciences presume to make translations. ${ }^{41}$

Bacon considers Greeks, Arabs, and Hebrews as 'enemies' of Christianity, Byzantium being schismatic and Muslims and Jews following a different religion. As a consequence, Bacon supposes that they are not particularly keen to provide the Latinate audience with the treasure of knowledge they have - why should they, if that science and wisdom will be used for the benefit of Latin Christendom? Without providing any proof -his line of reasoning is clearly highly rhetorical and politically motivated Bacon assumes that some of the unreliability of the Latin translations is due to the untruthfulness of the manuscripts acquired from these linguistic areas. Nonetheless, his criticism is again turned against the translators. Such detrimental commerce is possible only because the purchasers (i.e. the translators) are ignorant of what they are buying.

In this respect, Bacon appears to suppose that an application of the practical criteria be fundamental in order to respect the criterion of textual truthfulness. When a

41 Bacon, Compendium studii philosophiae, p. 174: 'Cum enim istis temporibus inimici Christianorum, ut Graeci et Arabes et Hebraei, habeant scientias apud linguas suas, non concedunt Christianis libros veraces sed detruncant et corrumpunt omnes, et maxime quando vident homines indoctos in linguis et scientiis praesumere de translationibus faciendis.' 
translator knows both language and science, she is able to discern between truthful and untruthful versions of a translatable text. By contrast, without meeting these criteria, or meeting only one of them, the result is the purchase and subsequent translation of a corrupt text whose effect would be detrimental for Latinate scholarship.

The problem with the translators' impossibility to assess the status of the translatable text is part of a wider question of accessibility. Although much scholarly attention has been focused on the latter, Bacon writes passionate and visionary pages about the staggering books Latinate society was missing. In this case, too, the responsibility for this lack of important works is ascribed to the translators, whose social function cannot be reduced solely to the production of a translated text. In the Opus maius Bacon recalls that, among philosophical texts, so many are missing:

Such is the second philosophy of Avicenna, which he calls oriental, which is devoted to pure philosophy, and does not fear the thrusts of the lances of contradicters, and the third, conterminous with his life, in which he collected secret experiments, as he noted in the introduction to his first philosophy. Likewise, although Aristotle completed the eight principal parts of natural philosophy containing in them many sciences, we do not have all of the first part, and almost nothing of the others. And in the same way although he himself completed the nine sciences composing mathematics, we have no part of his text. What we have on metaphysics can be reckoned of no value on account of many grave defects. Although there are five great sciences composing morals, we have only the first and a little of the second. Also there is missing from his logic a book better than the others, and the book next in excellence to it has been badly translated, and cannot be known, nor is it in general use, because it has come only lately into the hands of the Latins in a defective and rough translation. ${ }^{42}$

According to Bacon, these fundamental texts need to be sought and made available to the Latinate audience. Yet, who should look out for them? Implicitly, it seems that the translators should do so, since they alone have the capability to understand the importance and trustworthiness of a translatable text. This means that the translators have two interconnected functions in Latin society:

1. They seek new translatable texts.

2. They make available those translatable texts into Latin.

42 Bacon, Opus maius, bk. III, pp. 70-71: (...) ut est secunda philosophia Avicennae, quam vocant orientalem, quae traditur secundum puritatem philosophiae in se, nec timet ictus contradicentiurn lancearum; et tertia quae fuit contermina vitae suae, in qua experientias secretas congregavit, sicut ipse in prologo primae philosophiae suae annotavit. Et similiter cum Aristoteles complevit octo partes naturalis philosophiae principales, quae multas sub se continet scientias, de prima parte non habemus omnia, de aliis vero quasi nihil. Et eodem modo de metaphysica, quae sunt novem, cum ipse compleverit eas, nihil habemus quod de metaphysica una dignitate vocari potest propter defectus multiplices et praegrandes. De mathematicis vero, cum sint quinque scientiae magnae, non habemus nisi primam, et parum de secunda. Etiam de logica deficit liber melior inter omnes alios, et alius post eum in bonitate secundum male translatus est, nec potest sciri, nec adhuc in usu vulgi est, quia nuper venit ad Latinos et cum defectu translationis et squalore.' English trans. Belle Burke, vol. I, p. 79. 
In order to carry out both functions, they need to meet the two criteria of linguistic fluency and disciplinary mastery. However, the translators often lack these two prerequisites. Therefore, they are unable to find the texts needed for an advancement of Latin wisdom. And when they do find them, they are often unable to translate them..$^{43}$ Not being translated, these texts are kept away from Latinate scholarship, secluded and inaccessible.

Bad translations have detrimental effects on scholarship for two interconnected reasons. First, they are unreliable and deceptive, since they render the source domain in an untrustworthy fashion. Second, their audience does not have a sufficient knowledge of the languages of the source domains; therefore, the reader is unable to understand where and how the translation is unreliable. Bacon's criticism of the translators expands on the former. Following his reasoning, one can distinguish the detrimental effects of bad translations in two classes:

1. Mistakes in the understanding of the text rendered into Latin.

2. Mistakes in practicing the discipline in which the text is used.

The first class of mistakes (1) is grounded on how the original text is rendered into Latin at the two levels of terminology and phrasal semantics. Two main types of errors are implied at these levels. On the one hand, (a) the translator's scarce knowledge of vocabulary in both languages may result in the use of a mistaken Latin rendering, a calque, or a vernacularism. On the other hand, (b) the translator's lack of understanding of the original text may result in a mistaken rendering of entire sentences and paragraphs. Bacon gives examples of both types of mistakes. Concerning (1b), Bacon refers to the supposed mistakes in the Latin translation of Aristotle's theory of rainbow in Metereology III. According to him, Aristotle's theory is wrong only because the Latin translator of his work misunderstood and misrepresented it. ${ }^{44}$ In turn, Bacon discusses (1a) by recalling a personal anecdote:

Very many words from the Lombard language, the Hispanic, and the other languages of the Lat-
ins have been placed in the translated books. E. g., there is that of one of Aristotles' plants, be-
lenum - something very noxious in Persis but when transplanted in Jerusalem became edible.
When I lectured on this in my classes but did not know how to explain it, as was required,
my Spanish students derided me. I later learned from them that [the name] was not Arabic,
as all the doctors believe, but Spanish, and [the plant] is seed of henbane. (Herman, the trans-
lator, told me this.) And this is the way it is with uncountable other [words], granted the Latin
doctors do not realize it, nor are they embarrassed, even though they are ignorant of [correct]
interpretations. They take something to be Arabic or Greek and say they are excused [from in-

43 According to Bacon, this is the case of Herman the German's translation of Aristotelian logical works, which he possessed but 'did not dare to translate'. See Bacon, Compendium studii philosophiae, p. 176.

44 See Bacon, Compendium studii philosophiae, pp. 174-76: 'Verumtamen, ut excitem memoriam, sciat quilibet illud in tertio capitulo Meteorum Aristotelis esse falsissimum ubi dicitur quod iris non accidit ex radiis lunae nisi in quinquaginta annis bis, cum tamen potest contingere omni mense in plenilunio, si vapor dispositus sit in oppositum lunae et luna luceat in vigore.' 
dicating its meaning] because of their ignorance of languages since this ignorance is widespread. $^{45}$

Bacon had been deceived by the presence of the term 'belenum' in Nicholas of Damascus's De plantis, which Bacon as many other medieval philosophers believed was a work by Aristotle. Without knowing the meaning of the term, Bacon thought it was an Arabic calque but, apparently, it was a Spanish vernacularism, as Herman the German later told Bacon (again, supposedly). As a result, Bacon was ridiculed by his Iberian students; thus, he blames the translators for inserting mistaken or unintelligible terms into their translations. Bacon's anecdote, recalled also in the Opus maius and Opus tertium, attracted much of Théry's attention. ${ }^{46}$ His discussion of the Latin rendering from the Greek and through the Arabic versions of De plantis is remarkable. However, I agree with Franco Alessio in rejecting Théry's assumption that Bacon's criticism of the translator is grounded on this embarrassing episode of Bacon's teaching activity. ${ }^{47}$

Bacon's repetitive references to this anecdote do not seem to be linked to a personal grudge, but to the persuasive nature and the strict bond among the three works discussing the problem of translations. Moreover, the passage plays a specific role in the structure of the text. It refers to the real-life dimension and appeals to the possibility that many other practitioners among the readers of Bacon's works may have experienced something similar. And it certifies with a practical example what might otherwise appear as the elucubrations of a philosopher obsessed with languages and far removed from everyday life. Bacon's anecdote shows that this is not the case: mistakes are frequent, and it is easy to get caught in them, as his classroom experience confirms.

Bacon's example of the second kind of mistakes (2) are similarly characterized by references to real-life experiences. An unreliable translation obfuscates the true meaning of the text. As a result, it has despicable effects concerning the practitioners' use of that translation. Bacon refers to two crucial examples. The first is medicine. Because of calques and misrendered terms, physicians are unable to understand what ingredients should be used to make medicines, which prevents them

45 Bacon, Compendium studii philosophiae, pp. 162-64: 'Sunt etiam vocabula quamplurima de lingua Lombardicac, et Hispanica, et aliis Latinorum linguis posita in libris translatis, ut est illud de vegetabilibus Aristotelis, belenum, in Perside perniciosissimum, transplantatum Hierusalem factum est comestibile. Quod cum legi in scholis meis, et nesciretur interpretari, ut oportuit, deriserunt me Hispani scholares mei, a quibus postea didici quod non fuit Arabicum, ut omnes doctores credunt, sed Hispanum, et est semen cassilaginis. (Hermanus translator mihi dixit.) Et sic est de aliis innumerabilibus, licet hoc Latini doctores nesciant nec verecundantur, licet ignorent interpretationes, quia aestimant esse Arabicum vel Graecum et dicunt quod excusantur propter linguarum ignorantiam quia haec ignorantia est communis.'

46 See Bacon, Opus maius, bk. III, p. 67; and Opus tertium, bk. I, pp. 186-88. See also Théry, 'Note sur l'aventure "bélénienne",' pp. 140-47.

47 See Franco Alessio, Mito e scienza in Ruggero Bacone (Milan: Ceschina, 1957), pp. 44- 45. 
from properly using the texts. ${ }^{48}$ The second is philosophy. Bacon maintains that bad translations may give rise to philosophical controversies which could have been avoided were practitioners able to understand the real meaning of Aristotle's words:

A clear proof of this is the variety of opinions, because of which, however many studious men there be desirous of the truth of science, no one is in agreement with another. In one reading one says this, and another the contrary, and in a third the contradictory, a fourth something different, and however many others [they all pronounce] in accord with their own sense [of the text]. This also happens because now without parallel incomparably less is known about the philosophy of Aristotle than in olden times. ${ }^{49}$

As we have seen, a good, reliable translation of Aristotle's works, like those made by Grosseteste, would have helped avoid such pointless controversies. Yet, this is not enough. In order to properly understand a good translation, Bacon believes that one has nonetheless to know at least the basic aspects of the source language. Indeed, also good translations can and do generate controversial interpretations when they are not accompanied by some degree of understanding of the original language. These are the cases of false interpretations 'even when the letter is absolutely true' (etsi litera esset verissima). ${ }^{50}$ When lacking the required knowledge of the original language, the reader has to take a leap of faith: she has to substantively self-limit the possibility of her understanding of the text and delegate that epistemic disclosure to the translator alone. A perilous interpretative venture that, according to Bacon, should not be attempted.

\section{Conclusions}

Roger Bacon's rhetoric can be deceiving. As David C. Lindberg observes, 'Bacon was always making arguments, and many of them contain important philosophical points; but these were set adrift in a sea of rhetoric. ${ }^{51}$ This abrasive sea of rhetoric often attracts more attention than the refined doctrines that Bacon elaborates. The sections of Opus maius, Opus tertium, and Compendium studii philosophiae dedicated

\footnotetext{
48 See Bacon, Compendium studii philosophiae, p. 162: 'Medici enim in recepta medicinali inveniunt fere omnia vocabula herbarum et specierum et aliarum rerum medicinalium de aliis linguis vel pro magna parte. Et ideo non possunt intelligere quid libri dicant nec operari secundum quod ars medicinae requirit.'

49 Bacon, Compendium studii philosophiae, p. 164: 'Cuius etiam manifesta probatio est diversitas opinionum, quare, quantumcumque sint studiosi homines et desiderantes veritatem scientiae, nullus concordat cum alio. Sed in uno passu unus dicit hoc et alius contrarium et tertius contradictorium et quartus diversum et alii quotlibet iuxta sensum suum. Et hoc etiam accidit quia longe minus et sine comparatione scitur modo de philosophia Aristotelis quam antiquitus.'
}

50 See Bacon, Opus maius, bk. III, p. 81.

51 David C. Lindberg, 'On the Applicability of Mathematics to Nature: Roger Bacon and His Predecessors,' British Journal for the History of Sciences 15 (1982), p. 16 in pp. 3-25. 
to the medieval translators are marked by a corrosive style, personal attacks, and rhetorical exaggerations. Naturally, Bacon did not want to burn all of Aristotle's Latin translations. Nor did he believe that translations in general were useless or impossible - in fact, he worked mainly with translations and was extremely enthusiastic about Grosseteste's translating activity. Théry believes that much of Bacon's positive attitude toward Grosseteste's translations can be explained by his attachment to the Franciscan order and biases against the Dominicans. ${ }^{52}$ Surely, Bacon had biases, philosophically and methodologically. And it is beyond any doubt that he held Grosseteste's approach to science and philosophy in high regard. This does not mean, however, that we can reduce Bacon's perspective to some clerical partisanship. That would result in demoting Bacon's political and philosophical reflections substantively. If we do so with Bacon or any medieval actor, we should consistently apply the same criterion to modern scholarship, ending up in a storm of biases and historical-epistemic failures.

Our approach to a historically-determined philosophical text implies a series of considerations that sometimes needs to be repeated. We shall distinguish between the philosophical and non-philosophical contents of the text. Philosophy can and should be discussed in its theoretical dimension, in which the historical context can and does offer an epistemic surplus without determining its fundamental meaning. A fundamental part of this historical context is given by the non-philosophical contents of the text. These contents have a different set of epistemic coordinates and should be read accordingly. While it is highly unlikely that any philosopher exaggerated rhetorically their analysis of modal ontology or their stance on universals, it is quite possible that they exaggerate or even lie in their account of people, socio-political problems, and so on. In fact, any text is open to different levels of goal-directed functions. Although scholarship sometimes tends to imagine the text as if it were written for modern historians to help them in reconstructing its context, this is clearly not the case. A historical actor becomes a historical witness only by reason of the historian's interpretation of their accounts. Historians have to dissect the different levels of the text in consideration of their different goal-directed functions.

In a philosophical text broadly considered, at least three main levels are in place, each marked by goal-directed functions: 1 . the topical coordinates of the genre to which the text belongs; 2 . the historical contexts in which and toward which the text has been written; and 3. the theoretical kernel that the text expresses through a series of claims, stances, and refutations. Although intertwined, we shall not mistake the second for the third levels, nor overinterpret the first.

The historical context of Bacon's criticism of medieval translators is made clear by considering the works in which those stances are expressed. The three works are grounded thematically and chronologically on the Opus maius, of which the Opus tertium is an update and the Compendium a thematic development. The 
Opus maius was written with a precise function: to persuade the pope to start a reform of the education system in Latin Europe. Bacon's reform included the language training of a new generation of scholars that needed to be fluent in the ancient languages. Consistently, Bacon's attack on the translators is placed within the third section of the work, dedicated to the study of languages. And it is instrumental to that feature. There are other reasons why languages should be studied: access to knowledge is accompanied by reasons of foundation and practice. The problem of the Latin translations is only part of the context of Bacon's promotion of the study of languages. And within it, Bacon's criticism of the translations carries out an instrumental confirmative function of his main thesis: the pope ought to promote the study of languages through a reform of the education system.

Bacon's strategic aim is to persuade the pope that the pillars on which Christian wisdom is grounded (sacred texts in theology and Aristotle's works in philosophy) are rotten. This is why Bacon attacks so harshly the Latin translators of Aristotle's texts. He wanted to convince the pope that the bleak status of Christian wisdom included its very fundaments. And from there, it spread errors and controversies everywhere. Does this mean that Bacon actually thought that the translations made by Michael Scot or Gerard of Cremona were completely unreliable? That might be, but the purpose-driven political context of his discussion indicates that other non-theoretical motivations were in play. The thin line dividing rhetorical persuasion and philosophical commitment is difficult to discern, and it often originates a plurality of possible interpretations enriching the meaning of that text.

There is another aspect that is worth noticing. Descriptions of the bleak state of the Latin world are among the topical coordinates of medieval translations. Such descriptions were often used to justify the necessity of the translation and the novelty of its content..$^{53}$ Bacon seems to use a remarkably similar approach in his discussion of why languages should be studied, and translations remade in a better fashion. In both cases, the description of the supposedly miserable condition of Latin wisdom is instrumental to the justification of actions needed to better Christendom - a translation freshly made and a reform of knowledge and their translations to be made, respectively.

In this paper I have examined much of the theoretical core of Bacon's stance on translations and translators. Good translations can be identified when the two criteria of linguistic fluency and disciplinary mastery are met, and the translator is able to find a trustworthy version of the translatable text. The education reform that Bacon tried to introduce required translators to possess both language fluency and disciplinary mastery. Only by this set of skills, would they be able to render the complexity of

53 Good examples of this attitude are offered by the prologues to Avicenna's De anima and to Gundissalinus' translation of al-Farabi's De scientiis, among others. It is interesting to note that also original works directly connected to the translators seem to apply the same coordinates. See for instance, Daniel of Morley, Philosophia, ed. G. Maurach, Mittellateinisches Jahrbuch 14 (1979), pp. 212-13 in pp. 204-55. 
language and the meaning of a text into another language and its coordinates. And only through those skills would they be able to seek and find the many missing texts that Bacon so dearly craved. At the same time, Latinate readers must have a basic knowledge of the ancient foreign languages in order to 'go beyond' the Latin rendering of the text and appreciate its original meaning when it is necessary. Practitioners of philosophy, science, and theology need to have a basic understanding of the languages in which their main sources were written so as to gain more stable and reliable epistemic access to its theoretical content.

This means that a Latin scholar should have a qualifying knowledge of Greek to read Aristotle in Latin. In this way alone, the reader becomes a reflective reader able to discern, assess, and contingently interpret the meaning rendered by the translator. This is why, according to Bacon, the problem of translations is part of the study of language, and the latter is a crucial aspect of the overall reform of Latin education. 